\title{
Fen Bilimleri Öğretmenlerinin Sosyobilimsel Konular Hakkındaki Tutum ve Görüşlerinin Belirlenmesi*
}

\section{Rıdvan GÜRBÜZKOL ${ }^{* *}$ ve Hasan BAKIRCI ${ }^{* * *}$}

Öz: Bu çalışmanın amacı, Fen Bilimleri öğretmenlerinin sosyobilimsel konular hakkındaki tutum ve görüşlerinin belirlenmesidir. $\mathrm{Bu}$ çalışmada özel durum yöntemi kullanılmıştır. Çalışma, 2018-2019 eğitim-öğretim yılında Van il merkezi ve ilçelerinde görev yapmakta olan 289 (134-Kadın, 155-Erkek) Fen Bilimleri öğretmeni ile yürütülmüştür. Çalışmaya katılan Fen Bilimleri öğretmenleri içerisinde amaçlı örneklem yöntemi yardımıyla seçilen 10 öğretmen ile yarı yapılandırılmış mülakat yapılmıştır. Çalışmada veri toplama aracı olarak, Sosyobilimsel Konulara Yönelik Tutum Ölçeği (SOKTÖ) ve Yarı Yapılandırılmış Mülakat formu kullanılmıştır. Çalışmada elde edilen nicel veriler, tanımlayıcı istatistik tekniği kullanılarak analiz edilmiştir. Nitel verilerin çözümlenmesinde ise içerik ve betimsel analizden yararlanılmıştır. Çalışma sonucunda Fen Bilimleri öğretmenlerinin, sosyobilimsel konular hakkında yeterli bilgiye sahip oldukları, Fen Bilimleri dersinde bu konulara yer verdiklerini ve günlük hayatta önem verdikleri belirlenmiştir. Sosyobilimsel konuların toplumu ilgilendirmesi ve öğretim programında yer alması nedeniyle Fen Bilimleri öğretmenlerinin bu konularla ilgili bilimsel tartışmaları ve çalışmaları takip ettikleri sonucuna ulaşılmıştır. Sosyobilimsel konuların öğretimi, öğrencilerin başka düşünceye saygılı olmalarına, muhakeme ve eleştirel düşünme becerilerine katkı sağlamıştır. Fen Bilimleri öğretmenlerinin sosyobilimsel konular hakkındaki tutum ve görüşlerinin daha net görülebilmesi için geniş katılımlı çalışmaların yapılması önerilmektedir.

Anahtar Sözcükler: Fen bilimleri öğretmeni, sosyobilimsel konular, öğretmen görüşü.

\footnotetext{
*Bu çalışma, birinci yazarın Temmuz 2019 yılında biten yüksek lisans tezinden üretilmiştir.

**Uzman Fen Bilimleri Öğretmeni, Milli Eğitim Bakanlığı, Orcid ID: 0000-0002-8329-730X, E-mail: ridvan_gurbuzkol65@hotmail.com

***Doç. Dr. Van Yüzüncü Yıl Üniversitesi, Eğitim Fakültesi, Orcid ID: 0000-0002-7142-5271, E-mail: hasanbakirci09@gmail.com
}

Gönderim:12.02.2020 Kabul:05.05.2020 Yayın:15.06.2020




\section{Identifying Science Teachers' Attitudes and Opinions about Socio-scientific Issues}

Abstract: Stating opinions and attitudes of Science teachers about socio-scientific issues. The aim of this study is stating socio-scientific issues. At the study, special case method is used. In 2018-2019 academic year, the study is carried with 289 science teachers (134 women-155 men) who works around Van and its district. 10 Science teachers, who are chosen through science teachers attending the study with the help of purposeful sampling, are interviewed. As data collection tool, opinion and attitude about socio-scientific issues scale and semi-structured interview form is used. Quantitative data those are obtained at the study are analyzed by using descriptive statics technique. Content and description analysis help to analyze the qualitative data. At the end of the study, it is stated that science teachers have enough knowledge about socio scientific issues, teach these issues in their lessons and give importance in daily life. The teachers have positive attitude to socio-scientific issues and they follow the debates and studies because these issues affect society and figure on curriculum. According to teachers, these issues are polemic so they can respect to the others, have reasoning skills and think critical. To see clearly the opinions and attitudes of science teachers about socio-scientific issues, well-attended studying are offered

Keywords: Science teacher, socio-scientific issues, teacher opinion.

\section{Giriş}

Fen Bilimleri öğretmenlerinin sosyobilimsel konuların tartışmalı olması nedeniyle, bu konuların öğretiminde rehberlik etmede zorlandıkları bilinmektedir (Nielsen, 2012; Topçu, 2008). Bu durum, öğretmenlerin bu konularda yetersiz ve öğrencilerin farklı görüşlere sahip olmalarından kaynaklandığı düşünülmektedir (Sadler ve Zeidler, 2009). Buna karşın, bu konuda yeterli bilgisi olan öğretmenlerin ise kendi görüşlerini öğrencilere zorla kabul ettirme korkularının olmasının da büyük rolü olduğu söylenebilir. Bundan dolayı sosyobilimsel konuların öğretiminde öğretmenlerin çekimser davrandıkları bilinmektedir (Kılınç, Demiral ve Kartal, 2017). Öğretmenlerin sosyobilimsel konularda objektif düşünme ve başkalarının düşüncelerine saygılı olma ve bilimsel bilginin özelliğinden ayrılmamaları için Milli Eğitim Bakanlığı (MEB) tarafindan bu konuda onlara yeteri kadar hizmet içi eğitimin verilmediği söylenebilir (Topçu, 2017).

$\mathrm{Bu}$ konuda yapılan araştırmalar, Fen Bilimleri öğretmenlerinin sosyobilimsel konuları yeteri kadar öğrenemediklerini veya bu konularda eksiklerinin olduğunu göstermektedir 
(Cansız ve Cansız, 2015). Dolayısıyla bu eksiklere sahip Fen Bilimleri öğretmenlerinin de sosyobilimsel konuların öğretiminde zorlanacakları söylenebilir. Teknolojinin ve bilimin gelişmesiyle güncellenen bilgiler ve buna adapte olmaya çalışan okulların en büyük özelliği bilgilerin öğrencilere aktarılmasını sağlamaktır. Okulların bu konuları öğrencilere aktarabileceği en önemli derslerden birisi de Fen Bilimleri dersidir. Fen Bilimleri dersinin amacı bilinçli ve duyarlı öğrenciler yetiştirmektir. Buna öncülük edecek kişiler ise Fen Bilimleri öğretmenleridir. Bu yüzden Fen Bilimleri öğretmenleri öğrendikleri yöntemleri geliştirmeli ve farklı yollarla öğrencilere aktarmalıdır. Çünkü fen konularını tartışmayı ve sorgulamayı bilmeyen toplumların, toplumun getirdiği hurafe ve dogma bilgilerden kurtulamazlar (Kutluca, 2012).

Sosyobilimsel konular açık uçlu sorular taşıdığından karmaşıktır ve belirsizlikler içermektedir. Sosyobilimsel konular içeriklerini günlük hayatta karşılaşılabilecek durumlardan alır. Bundan dolayı bu konuların anlaşılıp öğrencilere de öğretilmesi fen eğitiminin önemli amaçları arasında bulunmaktadır (Albe, 2008; Nielsen, 2012). Sosyobilimsel konularda ele alınan ikilemler, etik kurallar ve toplumsal endişeler fen bilimlerinden ayrı düşünülmemelidir. Bu konularda bilinçli bireyler karar verirken etik, yasal, psikolojik ve medikal faktörlerin farkında olur ve karar verme sürecini etkiler (Demiral ve Türkmenoğlu, 2018). Bunun farkına varan öğrenciler çağdaş toplumun bir bireyi haline gelerek yetişir. Bu sebeple, öğrencilerin etik ikilemlerin bulunduğu konularda farkındalıklarının ve farklı görüşlere toleranslarının artırılması ve bu ikilemlerin çözümünde aktif olarak bulunmaları gereklidir (Dawson, 2011). Öğrencilerin bu konuları öğrenebilmesi ve aktif olabilmesi için öğretim programlarında sosyobilimsel konulara yer verilmesi gerekli olduğu düşünülmektedir.

Sosyobilimsel konuların öğretimine yönelik alanyazında birçok çalışma yer almaktadır. $\mathrm{Bu}$ çalışmalardan bazıları; yedinci sınıf öğrencilerinin sosyobilimsel konular hakkındaki görüşlerinin alınarak OBYM'ye dayalı fen öğretimi aracılı̆̆ıyla bu görüşlerin incelenmesi (Bakırcı, Artun, Şahin ve Sağdıç, 2018), fen eğitiminde sosyobilimsel aktivitelerle karar verme (Goloğlu, 2009), sosyobilimsel konuların argümantasyon destekli öğretimi (Domaç, 2011), sosyobilimsel konuların tartışma etkinlikleriyle desteklenmesi (Taşpınar, 2011), fen bilgisi öğretmen adaylarının sosyobilimsel konularda muhakeme yeteneklerinin geliştirilmesi (Cansız, 2014), yerel gazete haberlerinin ders dışı etkinlikle paylaşılması ve sunulması (Çapkınoğlu, 2015), küçük grupların tartışmaları (Kutluca, 2012; Soysal, 2012), tartışma, power point ve deney haftaları (Karışan, 2014) ve sosyobilimsel konularda sistem dinamiği yaklaşımı öğretimi (Nuhoğlu, 2014) şeklinde olduğu görülmüştür. 
Fen Bilimleri Dersi Öğretim Programı’nın temel felsefelerinden birisi de öğrencilerin fen okuryazar birey olmalarını sağlamaktır. Öğrencilerin okuryazar olmasında öğretmenlerin sosyobilimsel konulara bakışları, bilgi düzeyleri ve tutumları önemli rol oynamaktadır. Yapılan birçok çalışmada öğretmenlerin sosyobilimsel konularda yeterli olmaları öğrencilerin fen okuryazarlığg üzerinde etkili olduğu saptanmıştır (Clarkeburn, Downie ve Matthew, 2002; Wu ve Tsai, 2011). Sosyobilimsel konuları tartışabilecek bireylerin yetiştirilmesi aynı zamanda fen okuryazar bireylerin de yetişmesinde etki edeceği söylenebilir (Sadler ve Zeidler, 2005; Topçu, 2010). Fen Bilimleri öğretmenlerinin sosyobilimsel konular hakkındaki tutumları ve görüşleri öğrencilerin fen okuryazarlığı açısından büyük öneme sahip olduğundan, bu çalışmanın alanyazına katkı sağlayacağı düşünülmektedir.

Sosyobilimsel konular ile ilgili çalışmaların sonuçları analiz edildiğinde birçok olumlu sonuca ulaşılmıştır. OBYM temelli uygulamaların yedinci sınıf öğrencilerinin sosyobilimsel konularda karar verme yeteneklerinin gelişmesinde, günlük hayatta karşılaşacakları sorunları çözme becerilerinde ve bireylerin fen okuryazarlıklarının gelişmesinde etkili olduğu tespit edilmiştir (Bakırcı ve ark., 2018). Biyoloji öğretmenlerinin sosyobilimsel konuları sınıf içine transfer etmek için gerekli yeterlilikler açısından önemli eksikliklerinin olduğu saptanmıştır (Han-Tosunoğlu, 2018). Başka bir çalışmada ise Fen Bilimleri öğretmen adaylarının, Fen Bilimleri derslerine sosyobilimsel konuları entegre etmelerine yönelik öz-yeterlilik inançlarının düşük olduğu belirlenmiştir (Sıbıç, 2017). Fen öğrenme becerisi arttıkça fen okuryazarlık düzeylerinin ve sosyobilimsel konulara yönelik tutumlarının arttığ 1 , fen öğrenme becerisi azaldıkça fen okuryazarlık düzeylerinin ve sosyobilimsel konulara yönelik tutumlarının azaldığı görülmektedir (Yolagiden, 2017).

Sosyobilimsel konular ile ilgili yapılan çalışmalar incelendiğinde, sosyobilimsel konular hakkındaki görüşlerin araştırıldığı ve bununla birlikte sosyobilimsel konuların öğretiminde farklı öğretim yöntemlerinin kullanıldığı görülmektedir. Yapılan bu çalışmaların genellikle öğretmen adayları üzerine yoğunlaşmıştır. Bunun yanı sıra ortaokul ve lise öğrencileri ile çalışmaların yapıldığı tespit edilmiştir. Ancak Fen Bilimleri öğretmenlerinin örneklem olduğu ve sosyobilimsel konuların ele alındığı çalışmaların sınırlı olduğu anlaşılmıştır. Bundan dolayı Fen Bilimleri öğretmenlerinin sosyobilimsel konulara yönelik tutumlarının araştırılması, bu konudaki bilgileri ve bu konulara bakışları önemli hale gelmiştir. $\mathrm{Bu}$ bağlamda çalışmanın amacı; Fen Bilimleri öğretmenlerinin sosyobilimsel konular hakkındaki tutum ve görüşlerinin belirlenmesidir. $\mathrm{Bu}$ genel amaç doğrultusunda aşağıdaki problemlerin cevaplanması amaçlanmaktadır. 
1. Fen Bilimleri öğretmenlerinin sosyobilimsel konulara karşı tutumları nedir?

2. Fen Bilimleri öğretmenlerinin sosyobilimsel konuların öğretimi hakkındaki görüşleri nedir?

\section{Yöntem}

\section{Araştırmanın Deseni}

$\mathrm{Bu}$ çalışma, nicel ve nitel veri toplama araçlarının birlikte kullanılarak yapılan bir çalışmadır. Nicel ve nitel verilerin birlikte kullanımı, çalışmanın güvenirliği ve geçerliliğini arttırmaktadır. Yapılan çalışmada özel durum yöntemi kullanılmıştır. Özel durum yöntemi farklı veri toplama araçlarının bir arada kullanılarak bir durumun özelliği üzerine odaklanmayı sağlar (Cohen ve Manion, 1994). Ayrıca birden fazla veri toplama tekniği kullanılarak da verilerin birbirini sınaması ve desteklemesi beklenir (Yıldırım ve Şimşek, 2011).

\section{Örneklem}

Çalışmanın örneklemini, 2018-2019 eğitim-öğretim yılında Van merkez ilçelerinde görev yapmakta olan 289 Fen Bilimleri öğretmeni oluşturmaktadır. Bu öğretmenler içerisinde seçilen 10 Fen Bilimleri öğretmeni ile mülakat yapılmıştır. Mülakat yapılacak öğretmenlerin seçiminde tutum ölçeğinde alınan puanların aritmetik ortalaması dikkate alınmıştır. Tutum ölçeğinin aritmetik ortalaması yüksek, orta ve düşük olmak üzere üç gruba ayrılmıştır. Yüksek ve orta düzeyde 96 öğretmen yer alırken, düşük düzeyde 97 öğretmen yer almıştır. Yüksek ve orta düzeyde kura yardımıyla 3'er öğretmen seçilirken, düşük düzeyde 4 olmak üzere toplam 10 öğretmen mülakat için seçilmiştir. Kura ile seçilen öğretmenlerin öğretmenlerde gönüllü olmalarına da dikkat edilmiştir. Mülakat yapılan öğretmenler $F_{1}, F_{2}, F_{3} \ldots . . . F_{10}$ şeklinde kodlanmıştır.

\section{Veri Toplama Araçları}

Fen Bilimleri öğretmenlerinin sosyobilimsel konulara yönelik tutumlarını ölçmek amacıyla Topçu (2010) tarafından geliştirilen "Sosyobilimsel Konulara Yönelik Tutum Ölçeği (SOKTÖ)" kullanılmıştır. SOKTÖ, üç alt boyuttan ve 30 maddeden oluşmaktadır. Yapılan açımlayıcı ve doğrulayıcı faktör analizleri sonucunda, ölçeğin Cronbach alpha iç güvenilirlik katsayıları 0.70-0.90 arasında değişen üç boyutta toplandığı ortaya konmuştur. "Sosyobilimsel konuların yarar ve önemi” alt boyutunda Cronbach alpha iç güvenilirlik katsayısı 0.90, "Sosyobilimsel konulardan hoşlanma" alt boyutunda Cronbach alpha iç güvenilirlik katsayısı 0.81 ve son olarak "Sosyobilimsel konulara yönelik kaygı" alt boyutunda Cronbach alpha iç 
güvenilirlik katsayısı 0.70 olarak bulunmuştur (Topçu, 2010). Likert tipi olan bu ölçek "1Kesinlikle katılmıyorum”, "2-Katılmıyorum”, “3-Kararsızım”, “4-Katıllyorum”, “5Kesinlikle katılıyorum” gibi seçeneklere sahip beş dereceli bir ölçektir. Ölçekte yer alan dokuz maddenin (3, 5, 12, 16, 17, 19, 26, 28 ve 29. madde ) anlamca olumsuz olmasindan dolay1 bu maddelerin ters ( $1=$ Kesinlikle kat1lyorum; $5=$ Kesinlikle katılmıyorum) olarak tekrar kodlamas 1 yapılmıştır.

Araştırmanın nitel boyutu kapsamında, Fen Bilimleri öğretmenlerinin sosyobilimsel konular hakkında görüşlerini belirlemek üzere toplam on adet açık uçlu sorulardan oluşan yarı yapılandırılmış mülakat formu hazırlanmıştır. Hazırlanan bu formda yer alan soruların iç geçerliliğini sağlamak için bu sorular üç uzmana danışılmış ve uzmanların incelemeleri sonucunda mülakat formuna son hali verilmiştir. Uzmanların görüşleri alındıktan sonra soru sayısı beşe indirilmiştir. Görüşme, öğretmenlerin uygun olduğu zamanda yapılmıştır. Görüşmeler öğretmenlerden izin alınarak ses kayıt cihazı ile kayıt altına alınmıştır. Görüşmelerden elde edilen veriler metin haline dönüştürülmüştür. Mülakat formunda yer alan sorular aşağıda verilmiştir.

1. Sosyobilimsel konular denilince ne anlıyorsunuz?

2. Sosyobilimsel konular öğrenme ortamında nasıl öğretilmelidir?

3. Sosyobilimsel konuların öğretiminin öğrencilere sağladığı yararların neler olduğunu düşünüyorsunuz?

4. Sosyobilimsel konular hakkında yapılan bilimsel çalışmaları takip etme konusunda düşünceleriniz nelerdir?

5. Sosyobilimsel konular günlük hayat ile ilişkisi konusunda neler düşünüyorsunuz?

\section{Verilerin Analizi}

Likert tipi olan bu ölçekte olumlu ifadeler sırasıyla 5, 4, 3, 2, 1 olacak şekilde, olumsuz ifadeler ise sırasıyla 1, 2, 3, 4, 5 olacak şekilde puanlama yapılmıştır. Tutum ölçeğinin tanımlayıcı istatistik değerleri (aritmetik ortalama ve standart sapma) SPSS programı aracılığıyla hesaplanmıştır.

Yarı yapılandırılmış mülakatların çözümlenmesinde, betimsel ve içerik analiz tekniği kullanılmıştır. Mülakat formunda bulunan açık uçlu sorular Fen Bilimleri öğretmenlerine sorulmuş ve görüşmeler ses kayıt altına alınmıştır. Kaydedilen görüşmelerde araştırmacı tarafından çalışma problemi ile ilgili olmayan veriler çıkartılmıştır. Daha sonra kaydedilen ses kayıtları düz yazıya aktarıldıktan sonra araştırmacı ve iki farklı öğretim üyesi tarafından 
kodlamalar yapılmıştır. Verilerin güvenirliğini korumak için araştırmacı dışında iki fen eğitimcisine ham veriler verilerek onlardan çalışma problemi doğrultusunda tema ve kodlar çıkartılmıştır. Oluşturulan kodlamalar uzman eğitimci kodlamaları ile karşılaştırılmıştır. Oluşturulan her iki kodlamalar arasında farkın çok az olduğu görülmüştür. Bu kodlayıcılar arasındaki tutarlılık 0.83 olarak hesaplanmıştır (Miles ve Huberman, 1994). Daha sonra yapılan karşılaştırmalar da ortak kodlamalar oluşturulmuştur. Oluşturulan tema ve kodlar tablo şeklinde sunulmuştur.

\section{Bulgular}

Fen Bilimleri öğretmenlerinin SOKTÖ’de elde edilen bulgulara ilişkin betimsel istatistiksel değerleri Tablo 1'de verilmiştir.

Tablo 1. Fen Bilimleri Öğretmenlerinin Sosyobilimsel Konulara Yönelik Tutumlarına İlişkin Betimsel Değerlerin Dağılımı

\begin{tabular}{lccc}
\hline Ölçekteki Alt Boyutlar & N & $\bar{X}$ & Ss \\
\hline Sosyobilimsel konuların yarar ve önemi & 289 & 56.65 & 8.90 \\
\hline Sosyobilimsel konularda hoşlanma & 289 & 26.55 & 4.78 \\
\hline Sosyobilimsel konulara yönelik kayg1 & 289 & 33.14 & 6.08 \\
\hline Toplam ölçek tutum puanı & 289 & 38.78 & 6.50 \\
\hline
\end{tabular}

Tablo 1 incelendiğinde, Fen Bilimleri öğretmenlerinin SOKTÖ’nün sosyobilimsel konuların yarar ve önem boyutu puanlarının aritmetik ortalaması, 56.65 iken, sosyobilimsel konularda hoşlanma boyutu puanın aritmetik ortalamasının 26.55 ve sosyobilimsel konulara kaygı boyutu puanın aritmetik ortalaması 33.14 olduğu görülmektedir. Öğretmenlerin toplam SOKTÖ puanının aritmetik ortalaması ise 38.78 olduğu bulunmuştur.

Fen Bilimleri öğretmenlerinin sosyobilimsel konulara yönelik tutumlarının aritmetik ortalama ve standart değerleri Tablo 2'de verilmiştir. 
Tablo 2. Fen Bilimleri Öğretmenlerinin Sosyobilimsel Konulara Yönelik Tutumlarının Aritmetik Ortalama ve Standart Sapma Değerleri

\begin{tabular}{|c|c|c|c|}
\hline No & Maddeler & $\bar{X}$ & Ss \\
\hline 1 & Sosyobilimsel konular hakkında yeni gelişmeleri öğrenmek isterim & 4.19 & 1.08 \\
\hline 2 & Sosyobilimsel konular sürekli gelişen bilimi daha iyi anlamamı sağlar & 4.10 & 1.02 \\
\hline 3 & Sosyobilimsel gelişmeler sosyal açıdan yozlaştırmaktadır, bozmaktadır. & 3.84 & 1.15 \\
\hline 4 & Sosyobilimsel konular hakkındaki tartışmalar dikkatimi çeker. & 3.79 & 0.96 \\
\hline 5 & Sosyobilimsel gelişmeler ahlaki ve etik açıdan endişe vericidir. & 3.59 & 1.14 \\
\hline 6 & Sosyobilimsel konuları diğer bilimsel konulara göre daha çok severim. & 3.38 & 0.94 \\
\hline 7 & Sosyobilimsel konular ile beraber bilimsel konuları daha iyi öğrenirim. & 3.82 & 0.89 \\
\hline 8 & Sosyobilimsel konular çok sevdiğim bir alandır. & 3.67 & 0.90 \\
\hline 9 & Sosyobilimsel konuların günlük yaşantıda çok önemli yeri vardır. & 3.88 & 0.93 \\
\hline 10 & Medyadan sosyobilimsel konular hakkındaki gelişmeleri zevkle takip ederim. & 3.76 & 0.94 \\
\hline 11 & $\begin{array}{l}\text { Sosyobilimsel konular hakkında daha çok şey öğrenmenin önemli olduğunu } \\
\text { düşünüyorum }\end{array}$ & 4.03 & 0.88 \\
\hline 12 & $\begin{array}{l}\text { Sosyobilimsel gelişmeler sonucu ortaya çıkan uygulamaları dini açıdan uygun } \\
\text { bulmuyorum. }\end{array}$ & 3.67 & 1.09 \\
\hline 13 & Sosyobilimsel konular ile ilgili araştırma yapmak hoşuma gider. & 3.75 & 0.89 \\
\hline 14 & Sosyobilimsel konular hakkında daha çok şey öğrenmek isterim. & 3.99 & 0.83 \\
\hline 15 & $\begin{array}{l}\text { Sosyobilimsel konular günlük olaylarla ilgili olduğu için daha çok öğrenmek } \\
\text { isterim. }\end{array}$ & 3.94 & 0.81 \\
\hline 16 & $\begin{array}{l}\text { Sosyobilimsel konuların kötü amaçlı kişiler tarafından suistimal edileceğini } \\
\text { düşünüyorum. }\end{array}$ & 3.00 & 1.12 \\
\hline 17 & Sosyobilimsel konular hakkında tartışmaya katılmak bana cazip gelmez. & 3.64 & 1.02 \\
\hline 18 & $\begin{array}{l}\begin{array}{l}\text { Medyada(TV veya gazeteler) sosyobilimsel konulara daha fazla yer } \\
\text { verilmelidir. }\end{array} \\
\end{array}$ & 3.81 & 1.03 \\
\hline 19 & $\begin{array}{l}\text { Sosyobilimsel konulardaki gelişmelerin yarardan çok toplum için zararlarının } \\
\text { daha fazla olacağını düşünüyorum. }\end{array}$ & 3.79 & 1.11 \\
\hline 20 & $\begin{array}{l}\text { Sosyobilimsel konular hakkında ilginç bilgiler öğrenmek bende merak } \\
\text { uyandırır. }\end{array}$ & 3.90 & 0.88 \\
\hline 21 & $\begin{array}{l}\text { Çevremde gerçekleşen olayları sosyobilimsel konular hakkında öğrendiğim } \\
\text { bilgileri kullanarak anlamaya çalışmak hoşuma gider. }\end{array}$ & 3.89 & 0.86 \\
\hline 22 & $\begin{array}{l}\text { Sosyobilimsel konuların toplum üzerindeki olası olumsuz etkileri üzerinde } \\
\text { daha fazla bilgi sahibi olmak isterim. }\end{array}$ & 3.89 & 0.90 \\
\hline 23 & $\begin{array}{l}\text { Sosyobilimsel konular teknolojik gelişmeler üzerinde yeniden düşünmemizi } \\
\text { sağlar. }\end{array}$ & 4.01 & 0.80 \\
\hline 24 & Sosyobilimsel konular ile ilgili ek kaynaklar (internet, kitap vs) okurum. & 3.72 & 0.83 \\
\hline 25 & Sosyobilimsel konular üzerinde tartışmak düşünme yeteneğimizi geliştirir. & 3.96 & 0.88 \\
\hline 26 & Sosyobilimsel konular anlamaya çalışırken canım sıkılır. & 3.72 & 1.05 \\
\hline 27 & Sosyobilimsel konulara fen derslerinde daha çok yer verilmesini isterim. & 3.83 & 1.03 \\
\hline 28 & Sosyobilimsel konular ilgimi çekmez. & 3.98 & 1.04 \\
\hline 29 & $\begin{array}{l}\text { Sosyobilimsel konular hakkındaki uygulamalarda toplumsal değerlerin zarar } \\
\text { göreceğini düşünüyorum. }\end{array}$ & 3.91 & 1.00 \\
\hline 30 & Sosyobilimsel konuların toplum üzerinde yapacağı etkileri ilgimi çeker. & 3.91 & 0.85 \\
\hline
\end{tabular}

Tablo 2 incelendiğinde, ölçekteki 6 ve 16 nolu maddelere Fen Bilimleri öğretmenlerinin verdikleri cevaplar $\mathrm{X}_{6}=3.38, \mathrm{X}_{16}=3.00$ düzeyinde puan aldıkları görülmektedir. Likert tipi ölçeğin kriterlerine göre bu puan değerinin “Kararsızım”' seçeneğine tekabül ettiği söylenebilir. Aynı şekilde Tablo 2'den 1, 2, 11 ve 23 nolu maddeler incelendiğinde, Fen Bilimleri 
öğretmenlerinin verdikleri cevaplar $X_{1}=4.19, X_{2}=4.10, X_{11}=4.03, X_{23}=4.01$ puan değerleri şeklindedir. Bu puan değerleri 'aynı fikirdeyim '" önermesine karşılık gelen puan aralığında olduğu söylenebilir. Örneklemi oluşturan fen bilimleri öğretmenlerinin sosyobilimsel konulara yönelik tutumları incelendiğinde, genel olarak tutum puanlarının aynı fikirdeyim (3.40-4.19) düzeyinde oldukları belirlenmiştir.

\section{Yarı Yapılandırılmış Mülakat Formundan Elde Edilen Bulgular}

Çalışmaya katılan Fen Bilimleri öğretmenlerinin "Sosyobilimsel konular denilince ne anllyorsunuz? Sorusuna vermiş oldukları cevaplardan elde edilen tema ve kodlar Tablo 3’te verilmiştir.

Tablo 3. Fen Bilimleri öğretmenlerinin “Sosyobilimsel Konular Denilince Ne Anllyorsunuz?” Sorusuna Vermiş Oldukları Cevaplardan Elde Edilen Tema ve Kodlar

\begin{tabular}{|c|c|c|c|c|c|c|c|c|c|c|c|}
\hline Tema & Kodlar & $\mathbf{F}_{1}$ & $\mathbf{F}_{2}$ & $\mathbf{F}_{3}$ & $\mathbf{F}_{4}$ & $\mathbf{F}_{5}$ & $\mathbf{F}_{6}$ & $\mathbf{F}_{7}$ & $\mathbf{F}_{8}$ & $\mathbf{F}_{\mathbf{9}}$ & $\mathbf{F}_{10}$ \\
\hline \multirow{8}{*}{ 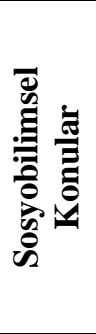 } & Toplumsal konular & + & + & + & + & + & + & + & + & + & + \\
\hline & Tartışmalı konular & + & + & - & + & - & + & + & + & + & - \\
\hline & Açık uçlu konular & + & + & + & + & - & + & + & + & - & + \\
\hline & Fen ile ilgili konular & + & + & + & - & + & + & - & - & + & + \\
\hline & Karmaşık konular & - & + & + & + & - & - & + & + & - & + \\
\hline & Bilim ve teknolojiyle ilgili konular & + & - & + & + & + & - & - & + & + & - \\
\hline & Çevresel sorunlar & + & + & + & - & + & - & - & - & - & - \\
\hline & Nükleer enerji santralleri & - & + & + & + & - & - & - & - & - & - \\
\hline
\end{tabular}

Tablo 3 incelendiğinde Fen Bilimleri öğretmenlerinin sosyobilimsel konular hakkındaki görüşlerine ilişkin görüşleri toplumsal, tartışmalı, açık uçlu, fenle ilgili, karmaşık konular olarak tanımladıkları görülmektedir. Bu konuda $\mathrm{F}_{1}$ kodlu öğretmen; "Tartışmaya açık, açık uçlu, çevreyi ve insanları etkileyen konulardır'" olarak belirtmiştir. Benzer şekilde $\mathrm{F}_{2}$ kodlu öğretmen "Fen bilimleri ve toplumsal hayatı ilgilendiren konuları içerdiğinden günümüzde sosyobilimsel konuların önemi artmaktadır ve gelişme açık bir alan olmaktadır.” Ayrıca çalışmaya katılan $\mathrm{F}_{3}$ kodlu öğretmen; "Sosyobilimsel konular tam bir tanımı olmamakla birlikte karmaşık, açık uçlu, bilim ve teknolojiyle ilgili konular olarak tanımlayabiliriz.” Şeklinde görüş belirtmiştir. Ayrıca bazı Fen Bilimleri öğretmenler ise bilim ve teknolojiyle, çevresel, nükleer enerji, sürdürülebilir kalkınma gibi konular olarak belirtmişlerdir. Bu alanda $F_{4}$ kodlu öğretmen "Sosyobilimsel konular bilim ve teknoloji, nükleer enerji, sürdürülebilir kalkınma gibi konuları içinde bulundurur.” Şeklinde tanımlamıştır. Ayrıca çalışmaya katılan $\mathrm{F}_{5}$ kodlu öğretmen; “Günümüzde gelişmekte olan bilim ve teknoloji ile birlikte sürdürülebilir kalkınmanın önemi artmaktadır. Bunun yanı sıra çevresel sorunlara da neden olabilecek sonuçlar ortaya çıkabilmektedir." Şeklinde açıklama yapmıştır. Benzer şekilde çalışmaya katılan $\mathrm{F}_{6}$ kodlu öğretmen; "Sosyobilimsel konuları fen ile ilgili olduğundan dolayı toplumun gelişmesine, kesin 
cevabı olmadığından dolayı da tartışma konular olarak tanımlayabiliriz". Şeklinde açıklama yapmıştır.

Fen Bilimleri öğretmenleri öğrenme ortamında sosyobilimsel konuların öğretimine ilişkin görüşleri Tablo 4’te verilmiştir.

Tablo 4. Fen Bilimleri Öğretmenlerinin "Sosyobilimsel Konular Öğrenme Ortamında Nasıl Öğretilmelidir? Sorusuna Vermiş Oldukları Cevaplardan Elde Edilen Tema ve Kodlar

\begin{tabular}{|c|c|c|c|c|c|c|c|c|c|c|c|}
\hline Tema & Kodlar & $\mathbf{F}_{1}$ & $\mathbf{F}_{2}$ & $\mathbf{F}_{3}$ & $\mathbf{F}_{4}$ & $\mathbf{F}_{5}$ & $\mathbf{F}_{6}$ & $\mathbf{F}_{7}$ & $\mathbf{F}_{8}$ & $\mathbf{F}_{9}$ & $\mathbf{F}_{10}$ \\
\hline \multirow{6}{*}{ 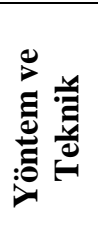 } & Tartışma yöntemi & + & + & + & + & + & + & + & + & + & + \\
\hline & Beyin firtınası tekniği & + & + & - & + & + & + & + & + & - & + \\
\hline & Örnek olay yöntemi & + & + & - & + & - & + & + & + & - & + \\
\hline & Münazara tekniği & - & + & + & - & + & + & + & - & + & + \\
\hline & Soru cevap yöntemi & + & - & + & + & + & - & + & + & + & - \\
\hline & Argümantasyon & + & + & - & + & - & - & - & + & + & - \\
\hline \multirow{4}{*}{ 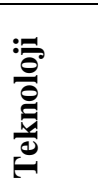 } & Ak1llı tahtanın kullanılması & + & + & + & + & - & + & + & + & - & + \\
\hline & Projeksiyon cihazının kullanılması & + & - & + & + & + & - & + & - & + & + \\
\hline & Simülasyon & + & - & + & + & + & - & - & - & - & - \\
\hline & Animasyon & + & - & - & + & + & - & - & + & - & - \\
\hline
\end{tabular}

Tablo 4 incelendiğinde, Fen Bilimleri öğretmenleri sosyobilimsel konuların öğretimine ilişkin görüşleri iki tema altında toplandığı görülmektedir. Öğretmenler, sosyobilimsel konuların öğretiminde tartışma, beyin fırtınası, örnek olay, soru cevap ve argümantasyon gibi yöntem/teknikleri ile öğretilmesi gerektiğini dili getirmişlerdir. Tartışma kodu ile görüş beyan eden $\mathrm{F}_{7}$ kodlu öğretmen; "Sınıf ortamında öğrencilerin zihninde canlanması için örnek olay ve soru-cevap yöntemini kullanarak ögrencilerin sosyobilimsel konuların öğrenmelerini sağlarız." Şeklinde görüş beyan etmiştir. Ayrıca çalışma katılan $F_{8}$ kodlu öğretmen ise görüşünü; “Öğrencilere öncelikle beyin firtınası olacak şekilde sorular yöneltirim daha sonra öğrencilerin verdikleri cevaplar tartı̧̧ma ortamında tekrar öğrencilerle birlikte konunun yararll ve zararlı yönlerini belirleyerek dersi işlerim." Şeklinde açıklamıştır. Benzer şekilde F9 kodlu öğretmen ise “Öğrencilerle konuları işledikten sonra bazı konularda iki grup oluşturarak konunun yararları ve zararlarını öğrencilerin münazara yapacak şekilde anlatmalarına olanak sağllyoruz. " Şeklinde görüşünü belirtmiştir. Ayrıca bazı Fen Bilimleri öğretmenleri akıllı tahta, projeksiyon, simülasyon, animasyon gibi teknolojik araçları ile konunun öğretilmesi gerektiği şeklinde görüşlerini dile getirmişlerdir. Akıllı tahta kodu ile görüşünü görüş beyan eden $F_{4}$ kodlu öğretmen "Sinıflarda kurulu olan akıllı tahtalar sayesinde sosyobilimsel konulart öğrencilere videolar izleterek daha iyi ögrrenmelerini sağlarız.” Şeklinde görüş beyan etmiştir. Benzer şekilde çalışmaya katılan Fo kodlu öğretmen "Sınıflarda projeksiyon cihazı yardımı ile sosyobilimsel konuları öğrencilere görsel bir şekilde aktararak öğrencilerin bu konuları daha iyi ögrenmelerini ve bilgiler daha kalıcı hale gelir." Şeklinde açıklama yapmıştır. 
Fen Bilimleri dersi kapsamında sosyobilimsel konuların öğretiminin öğrencilere sağladığ 1 katkılara ilişkin öğretmenlerin görüşleri Tablo 5'de verilmiştir.

Tablo 5. Fen Bilimleri Öğretmenlerinin "Sosyobilimsel Konuların Öğretiminin Öğrencilere Sağladı̆g Yararların Neler Olduğunu Düşünüyorsunuz” Sorusuna Vermiş Oldukları Cevaplardan Elde Edilen Tema ve Kodlar

\begin{tabular}{|c|c|c|c|c|c|c|c|c|c|c|c|}
\hline Tema & Kodlar & $\mathbf{F}_{1}$ & $\mathbf{F}_{2}$ & $\mathbf{F}_{3}$ & $\mathbf{F}_{4}$ & $\mathbf{F}_{5}$ & $\mathbf{F}_{6}$ & $\mathbf{F}_{7}$ & $\mathbf{F}_{8}$ & $\mathbf{F}_{\mathbf{9}}$ & $\mathbf{F}_{10}$ \\
\hline \multirow{7}{*}{ 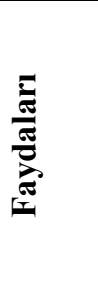 } & Karar verme becerisini geliştirme & + & + & - & + & - & + & + & + & + & + \\
\hline & Yorum yapma becerisini geliştirme & + & + & + & - & + & + & - & - & + & - \\
\hline & Empati kurma becerisini geliştirme & + & + & - & + & - & + & + & - & + & - \\
\hline & Görüşünü gerekçesi ile açıklama & + & + & - & + & + & + & - & + & - & + \\
\hline & Eleştirel düşünme becerisini geliştirme & + & - & + & - & - & - & + & - & - & + \\
\hline & Farklı görüşlere saygıllı olmayı öğrenme & + & - & + & + & + & - & - & + & - & - \\
\hline & Problem çözme becerisini geliştirme & + & + & - & - & - & + & - & - & + & + \\
\hline
\end{tabular}

Fen Bilimleri öğretmenlerinin sosyobilimsel konuların öğretiminde öğrencilere sağladığı yararları konusundaki görüşleri Tablo 5'de toplandığı görülmektedir. Fen Bilimleri öğretmenleri sosyobilimsel konuların öğrencilere sağladığı yararları; karar verme, yorum yapma, empati kurma, görüşünü savunma şeklinde dile getirmişler. Bu konuda görüşünü belirten $\mathrm{F}_{9}$ kodlu öğretmen; “Öğrenciler konular hakkında yorum yaparken aynı zamanda kendi kararlarını da verirler. Bazı durumlarda kendilerini başkalarının yerine de koyabilirler." diyerek düşüncesini dile getirmiştir. Benzer şekilde çalışmaya katılan $F_{10}$ kodlu öğretmen “Öğrenciler sosyobilimsel konular hakkında karar verirken aynı zaman da kendi görüşlerini de savunarak düşüncelerinin önemli olduğunun farkına varırlar." Şeklinde görüş belirtmiştir.

Tablo 5 incelendiğinde, bazı Fen Bilimleri öğretmenleri eleştirel düşünme, görüş değiştirme, problem çözme gibi öğrencilerin gelişimine yarar sağladığını dile getirmişler. Görüş değiştirme konusunda düşüncelerini dile getiren $\mathrm{F}_{6}$ kodlu öğretmen; "Bazı sosyobilimsel konuları sınıf ortamında tartışıldığı zaman bu konular hakkında fazla bilgi sahibi olmayan ögrenciler konuyu öğrenmelerinin yanı sıra görüşlerinde değişme meydana geliyor,” şeklinde açıklamıştır. Aynı şekilde çalışmaya katılan $\mathrm{F}_{2}$ kodlu öğretmen; "Sosyobilimsel konular ögrencilerin günlük hayatta karşılaşacakları problemleri tanımasını ve bu problemleri nasıl çözmesi gerektiğini öğrenmelerine yardımcı oluyor.” Şeklinde görüş beyan etmiştir.

Çalışmaya katılan Fen Bilimleri öğretmenlerinin sosyobilimsel konularla ilgili bilimsel araştırmaları takip etmelerine ilişkin görüşleri Tablo 6'da verilmiştir. 
Tablo 6. Fen Bilimleri Öğretmenlerinin "Sosyobilimsel Konular Hakkında Yapılan Bilimsel Çalışmaları Takip Eder Misiniz” Sorusuna Vermiş Oldukları Cevaplardan Elde Edilen Tema ve Kodlar

\begin{tabular}{|c|c|c|c|c|c|c|c|c|c|c|c|}
\hline Tema & Kodlar & $\mathbf{F}_{1}$ & $\mathbf{F}_{2}$ & $\mathbf{F}_{3}$ & $\mathbf{F}_{4}$ & $\mathbf{F}_{5}$ & $\mathbf{F}_{6}$ & $\mathbf{F}_{7}$ & $\mathbf{F}_{8}$ & $\mathbf{F}_{\mathbf{9}}$ & $\mathbf{F}_{10}$ \\
\hline \multirow{6}{*}{ 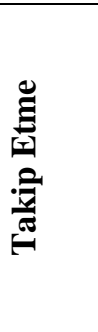 } & Bu konuların fen dersinde yer alması & + & + & + & + & - & + & + & + & + & + \\
\hline & Sosyobilimsel konuların güncel olması & + & + & + & - & + & + & - & - & + & - \\
\hline & Toplumu ilgilendiren konular & - & + & + & + & - & + & + & - & + & + \\
\hline & Tartışmalı konular olması & + & + & - & + & + & + & - & + & - & + \\
\hline & $\begin{array}{l}\text { İnsan sağlığını doğrudan } \\
\text { konular }\end{array}$ & + & - & + & - & - & - & + & - & - & + \\
\hline & $\begin{array}{l}\text { Teknolojinin gelişimi doğrudan ilgili } \\
\text { olması }\end{array}$ & + & - & + & + & + & - & - & + & - & - \\
\hline
\end{tabular}

Tablo 6 incelendiğinde, sosyobilimsel konular hakkında bilimsel araştırmaları takip eden Fen Bilimleri ögretmenleri, fen dersinde yer alması, güncel olması, toplumsal olması ve teknolojinin gelişimiyle ilgili olduğundan dolayı sosyobilimsel konuları takip etmektedirler. $\mathrm{Bu}$ konuda görüşünü belirten F9 kodlu öğretmen; "Fen bilimleri branşından dolayl, aylık ya da yıllık çıkan bilim teknik dergileri ve toplumsal konular ile ilgili olduğundan bu alanda yapılan bilimsel çalışmaları takip ederim.” diye belirtmiştir. Ayrıca çalışmaya katılan $\mathrm{F}_{5}$ kodlu öğretmen ise görüşünü; "Günümüzde gelişen teknoloji ile birlikte bu gelişim toplumu etkilemektedir. Toplumun teknoloji ile birlikte gelişmesi daha fazla önem kazanmaktadır. Bu yüzden gelişimim için bu konuları hakkında yapılan bilimsel çalışmaları araştırır ve takip ederim.” şeklinde görüş beyan etmiştir.

Çalışmaya katılan Fen Bilimleri öğretmenlerinin sosyobilimsel konuların günlük hayatla ilişkisine yönelik görüşleri Tablo 7'de verilmiştir.

Tablo 7. Fen Bilimleri Öğretmenlerini “Sosyobilimsel Konular Günlük Hayat İle İlişkisi Konusunda Neler Düşünüyorsunuz?” Sorusuna Vermiş Oldukları Cevaplardan Elde Edilen Tema ve Kodlar

\begin{tabular}{|c|c|c|c|c|c|c|c|c|c|c|c|}
\hline Tema & Kodlar & $\mathbf{F}_{1}$ & $\mathbf{F}_{2}$ & $\mathbf{F}_{3}$ & $\mathbf{F}_{4}$ & $\mathbf{F}_{5}$ & $\mathbf{F}_{6}$ & $\mathbf{F}_{7}$ & $\mathbf{F}_{8}$ & $\mathbf{F}_{9}$ & $\mathbf{F}_{10}$ \\
\hline \multirow{7}{*}{ 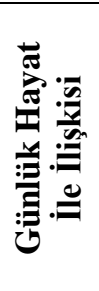 } & Toplumsal sorunlara neden olması & + & + & + & + & - & - & + & + & + & + \\
\hline & Canlıların yaşamında önemli olması & + & - & + & + & + & + & - & + & + & - \\
\hline & Çevreyi doğrudan etkilemiş olması & + & - & + & + & - & + & + & + & - & + \\
\hline & Besinleri doğrudan etkilemiş olması & - & + & - & + & + & + & - & + & - & - \\
\hline & Teknoloji gelişiminde etkilenme & + & + & - & - & + & - & + & - & + & + \\
\hline & Ekonomik sebeplerin ortaya çıkarması & - & + & + & - & - & - & - & - & + & - \\
\hline & Ülkeler arası rekabetin olması & + & - & - & + & - & + & - & + & - & - \\
\hline
\end{tabular}

Tablo 7 incelendiğinde, Fen Bilimleri öğretmenlerinin sosyobilimsel konuların günlük hayatla ilişkisini toplumsal sorunlarına neden olması, canlıların yaşamında önemli olması, çevreyi doğrudan etkilemiş olması, teknolojinin gelişiminde etkilenme, ekonomik nedenler ve ülkeler arası rekabet olarak dile getirmişler. Bu konuda $\mathrm{F}_{4}$ kodlu öğretmen; "Sosyobilimsel konular insanların gündelik hayatlarını etkiler durumdadır. Toplumun sorunları oluştukça bu sorunlar çevreye de etki eder ve canlı yaşamını olumsuz etkileyebilir." Şeklinde tanımlamıştır. 
Aynı zamanda çalışmaya katılan $\mathrm{F}_{5}$ kodlu öğretmen; "Sosyobilimsel konular canlıların yaşamı üzerindeki etkisi canlıların beslenmesiyle de ilgilidir. Özellikle genetiği değiştirilmiş organizmaların (GDO) canlıların gelişimine ve să̆lı̆̆ına etki etmektedir." Şeklinde görüşünü dile getirmiştir. Benzer şekilde çalışmaya katılan $\mathrm{F}_{8}$ kodlu öğretmen; “Günlük hayatta alınan bazı besinlerin insan sağlığına etkisi ve bazı ilaçlar insan yaşamını olumlu veya olumsuz yönde etkileyebiliyor ve etki de bazı ülkelerin ilaçlarını başka ülkelerden alınmasıyla birlikte ekonomilerini etkilemektedir." Şeklinde görüş beyan etmiştir.

\section{Tartışma ve Sonuç}

Fen Bilimleri öğretmenlerin tutum ölçeğinde yer alan üç alt boyutlarına ilişkin ortalama puanlarının farklı olduğu tespit edilmiştir (Bkz. Tablo 1). Öğretmenlerin sosyobilimsel konuların yarar ve önemi konusundaki maddelerin ortalama puanı yüksek çıkarken, tutum, hoşlanma ve kaygı maddelerine yönelik maddelerin ortalama puanlarının düşük çıktığ belirlenmiştir. Öğretmenlerin sosyobilimsel konuların önemi konusunda olumlu görüş bildirmelerinde, sosyobilimsel konuların öğretim programında yer alması, sosyobilimsel konuların görsel ve yazılı basında sürekli gündemde olması ve sosyobilimsel konular hakkında bilgi edinilmesi insanların sağlıklı yaşamlarında önemli olması ile açıklanabilir. Topçu, Muğaloğlu ve Güven (2014) yapmış olduğu çalışmasında sosyobilimsel konuların öğretim programında yer almasıyla birlikte öğretmenlerin sosyobilimsel konuları araştırdıkları ve bu konuda hizmet içi eğitim almaları konusunda istekli olduklarını belirtmiştir. Sosyobilimsel konuların yazılı ve görsel basında yer almasıyla uzmanlar tarafından daha çok tartışıldığ görülmüştür (Sadler, 2004; Yahaya, Zain ve Karpudewan, 2012). Bu açıdan bakıldığında Fen Bilimleri öğretmenlerinin sosyobilimsel konular hakkında bilgili olmaları, bu konuda belirli görüş ve tutuma sahip olmalarının alan yazındaki çalışmaların sonuçlarıyla benzerlik gösterdiği söylenebilir.

Fen Bilimleri öğretmenlerinin sosyobilimsel konulardan hoşlanmadığg ve kayg1 duydukları tespit edilmiştir. Öğretmenlerin sosyobilimsel konulardan hoşlanmama ve kaygılarının olması bu konuların tartışmaya açık ve bu konularda fikir birliğinin olmamasıyla ilişkilendirilebilir. Çalışmanın yapıldığı çevrenin dini inanışları bakımından muhafazakâr olmaları, ailelerin sosyobilimsel konulara bakış açılarının olumsuz olması bu durumun öğrencilere yansımış olmasının da etkili olduğu söylenebilir. Örneğin öğretmen derste taşıyıcı anne ve sperm bankaları ile ilgili sosyobilimsel konulara örnek verirken öğrencilerden gelen tepkilerden çekinmektedirler. Çünkü bu konular Hıristiyan olan topluluklarda normal 
karşılanırken İslam toplumlarında normal karşılanmamaktadır. Ayrıca öğrencileri sınava hazırlamaya yönelik yöntem ve tekniklerle dersi işleyen Fen Bilimleri öğretmenleri sosyobilimsel konuların açık uçlu, tartışmalı konular olmasından dolayı derslerde bu konulara fazla yer vermemektedir. Bunun sonucunda öğretmenlerin sosyobilimsel konulardan hoşlanmadıkları ve kaygı duydukları söylenebilir. Uluslararası bazı çalışmalarda da öğretmenlerin sosyobilimsel konuları derslerinde işlemelerinde sıkıntılar yaşandığı görülmektedir (Hogan, 2002; Roth ve Lee, 2004; Zeidler, Sadler, Applebaum ve Callahan, 2009). Öğretmenler bilimsel ilkeleri ve bilimsel süreç becerilerini öğretirken bilimin farklı açılarını yük olarak görebilmektedir.

Fen Bilimleri öğretmenlerinin tutum ölçeğindeki ortalama değerlerine bakıldığında genellikle 3.40-4.19 puan aralığında olduğu görülmektedir (Bkz. Tablo 2). Bu bulgu öğretmenlerin sosyobilimsel konulara yönelik olumlu tutuma sahip olduklarını ve belirli düzeyde bilgi sahip oldukları şeklinde yorumlanabilir. Yolagiden (2017)’de, öğretmen adaylarının sosyobilimsel konulara yönelik ilişkin tutumlarının orta seviyenin üstünde olduğunu belirlemiştir. Fen Bilimleri ders kitaplarında ve kazanımlarında sosyobilimsel konular ile ilgili bilgilerin yer alması öğretmenlerin bu konular hakkında olumlu bir tutuma ve fikre sahip olmalarına katkı yaptığı düşünülmektedir

Fen Bilimleri öğretmenlerinin sosyobilimsel konular hakkında birçok fikir beyan ettiğ $i$ görülmüştür (Bkz. Tablo 3). Öğretmenler sosyobilimsel konuları, tartışmalı, açık uçlu ve fen ile ilgili konular şeklinde açıklamışlardır. Bunun yanında toplumu ilgilendiren, insanlar tarafindan fikir birliğine varılmayan ve çevre sorunları ile ilişkilendiren açıklamalar yaptıkları da belirlenmiştir. Öğretmenlerin bu açıklamalarında sosyobilimsel konuların öğretim programında yer almasından dolayı araştırma yapmaları bu konuda yapılan bilimsel çalışmaları takip etmeleri ve ders kitabında sosyobilimsel konuların yer almasının etkili olduğu düşünülmektedir. Bunun yanı sıra bilim ve toplumu ilgilendiren problemlerin günlük hayatta sürekli göz önünde olması ve güncelliğini koruması da öğretmenlerin sosyobilimsel konular hakkında fikir sahibi olmalarına katkı sağlamıştır. Bu konuda yapılan çalışmalar incelendiğinde sosyobilimsel konuları hem bilimsel hem de sosyal ikilemler içeren problemler şeklinde tanımlanmıştır (Sadler ve Zeidler, 2005). Benzer şekilde Topçu (2010) çalışmasında sosyobilimsel konuları karmaşık, kesin cevabı olmayan konular şeklinde tanımlamıştır. Öğretmenlerin bu çalışmada sosyobilimsel konuları alan yazında geçtiği gibi tanımladıkları sonucuna ulaşılmıştır. 
Fen Bilimleri öğretmenleri, sosyobilimsel konuların öğretiminde beyin firtınası tekniği, örnek olay, münazara ve soru-cevap tekniği kullanılması gerektiğini belirtmişlerdir (Bkz. Tablo 4). Öğretmenlerin bu şekilde düşünmeleri, bu öğretim tekniklerinin öğrenci merkezli olması, tartışmaya imkân vermesi ve toplumu ilgilendiren örnek olayın sınıfa taşınmış olması gibi unsurların etkili olmasıyla açıklanabilir. Örneğin beyin firtınası tekniğinin her öğrencinin kendi fikrini söylemesi, öğrencilerin farklı düşüncelere karşı saygılı olması ve orijinal fikirler üretilmesi gibi yararları bulunmaktadır. Ayrıca bazı öğretmenler de akıllı tahta, simülasyon, projeksiyon ve animasyon şeklinde genellikle görsel ağırlıklı yöntem ve tekniklerin kullanılması şeklinde görüşlerini dile getirmişler. Öğretmenlerin bu şekilde düşünmeleri, çağın teknoloji çağı olması, öğrencilerin teknoloji destekli derslere ilgi duyması ve teknolojik araçların birden çok duyu organlarına hitap etmesiyle açıklanabilir. Öğretmenlerin, okullarında bulunan teknolojik aletlerin alt yapılarının bulunmasının, okul ve çevresinin bu ortama uygun olmasının, öğrencilerin daha iyi öğrenmelerini sağladığ 1 , ders anlatım zamanının daha verimli olduğu, zamandan tasarruf sağladığı ve öğrencilerde kalıcı öğrenmeler oluşturduğu söylenebilir (Öztürk, Akdeniz ve Bakırcı, 2017).

Fen Bilimleri öğretmenleri, sosyobilimsel konuların öğrencilere karar verme, yorum yapma, empati kurma, kendi görüşünü savunma, eleştirel düşünme, görüş değiştirme ve problem çözme gibi özellikler kazandırdığını ifade etmişlerdir (Bkz. Tablo 5). Öğretmenlerin bu şekilde düşünmelerinde; fen öğrenme ortamlarında münazara, forum, açık oturum, kollegyum ve panel gibi tartışma tekniklerine yer verilmesinin etkili olduğu ifade edilebilir. Çünkü kullanılan bu tekniklerle öğrenciler sahip oldukları bilgileri kendileri oluşturabilmekte, okudukları konular hakkında fikir sahibi olabilmekte, başka insanların fikirlerine saygı duyabilmekte ve böylece kendi fikir yapılarını da değiştirebilmektedir. Sosyobilimsel konular hakkında bilgi sahibi olan öğrencilerin, bu konuları günlük hayatta daha rahat tartışabildikleri, yorum yapabildikleri ve bu konuda fikirlerini daha rahat ifade edebildikleri söylenebilir. Alanyazında yapılan çalışmalarda sosyobilimsel konuların farklı öğretim kademesindeki öğrencilerin karar verme, eleştirel düşünme ve muhakeme becerilerini geliştirdiği sonucuna ulaşılmıştır (Albe, 2008; Zeidler ve ark., 2009). Yapılan birçok çalışmada, öğrencilerin sosyobilimsel konular hakkında yeterli bilgiye sahip olmaları, onların bu konuda fikir yürütmelerine, çözüm önerileri sunmalarına, yeni fikirler üretebilmesine ve fikirlerinin değişmesine yol açmıştır (Ebenezer, Chacko, Kaya, Koya ve Ebenezer 2010; Demircioğlu ve Vural, 2016). Benzer şekilde Lee ve Erdoğan (2007) yaptıkları çalışmada, sosyobilimsel 
konularla ilgili yapılan öğrenme ortamlarının öğrencilerin Fen Bilimleri dersine karşı pozitif yönde etkilediğini tespit etmişlerdir.

Fen Bilimleri öğretmenleri, sosyobilimsel konular hakkında yapılan bilimsel çalışmaları takip ettiklerini belirtmişlerdir (Bkz. Tablo 6). Bilimsel çalışmaları takip eden öğretmenler sosyobilimsel konuların fenle ilgili olması, bilimsel olması, toplumsal olması ve gün geçtikçe teknolojinin gelişmesine bağlı olarak takip ettiklerini açıklamışlardır. Bu durum, her geçen gün gelişen teknoloji ile birlikte toplumda yeni gelişmelerin ve ihtiyaçların ortaya çıkmaya başlaması ile açıklanabilir. Çünkü bu gelişme ve yenilikler insanlarda merak uyandırmakla birlikte günlük hayatta karşılaşılan olaylara ilgi duymalarına ve bu olayları bilimsel olarak açıklamaya çalışmasına olanak sağlamaktadır (Karaaslan ve Ayas, 2016; Sağlam, Karaaslan ve Ayas, 2014). Bununla birlikte bireyler, hem var olduğu dünya hakkında hem de gelişen teknoloji ile birlikte hayatımızı kolaylaştıracak yeni icatlar hakkında bilgi sahibi olmaya çalışmaktadır. Bu icatları günlük hayatta kullanmak için bilgilenmeleri gerektiği düşüncesi sosyobilmsel konular hakkında yapılan çalışmaları takip etme nedeni olabilir. Cebesoy ve Dönmez-Şahin (2013) yaptığı çalışmada, fen bilimleri öğretmen adaylarının sosyobilimsel konular hakkında araştırma yapmaları ve bu konuda bilinçli olmaları gerektiğini belirtmiştir.

Fen Bilimleri öğretmenleri sosyobilimsel konuların günlük hayatla ilişkisini toplumda sorunlara neden olması, canlıların yaşamını doğrudan etkilenmesi, çevreyi olumsuz etkilemesi besinlerin yapısında yer alması gibi kavramlarla ilişkilendirerek açıklamışlardır (Bkz. Tablo 7). Diğer taraftan çalışmaya katılan bazı öğretmenler ise sosyobilimsel konuları teknolojinin gelişmesi, ekonomik sebepler ve ülkeler arası rekabet gibi kavramlar bağlamında ifade etmişlerdir. Öğretmenlerin bu görüşlerinde teknolojinin getirmiş olduğu fayda ve zararlarının etkili olduğu düşünülmektedir. Teknoloji alanında yapılan çalışmalar, üretilen ilaçların bazı hastalıkların tedavisinde kullanılması veya bunun yanında bazı ilaçlarında hastalıklara neden olabilmesi bazı ülkelerin yaşam standartlarını yükseltmek ve ülkelerinin gelişmişlik düzeyini yükseltmeye çalışması ile birlikte diğer ülkeler ile rekabet haline girmesiyle açıklanabilir. Ülkelerin rekabet halinde olması ve bu ülkelerin ekonomilerini ileri bir düzeye taşımalarında önemli bir yere sahip olan sosyobilimsel konuların önemi gün geçtikçe artmaktadır. Öğretmenlerin sosyobilimsel konuların günlük hayat ile ilişkisi konusunda görüş bildirmeleri, bu konuların görsel ve yazılı basında gündemde olması, teknolojinin gelişmesiyle birlikte çevreye etkisi ve çevreninde canlı yaşamını etkilemesi olarak söylenebilir (Bakırcı ve ark., 2018). Diğer taraftan ülkelerin gelişmişlik düzeylerini ve hayat standartlarını arttırma çabaları, bazı ülkelerin bilim alanında yaptıkları çalışmalarla bazı hastalıkların tedavisini bulması ve 
buldukları ilaçları başka ülkelere satarak ekonomilerinin diğer ülkelerin ekonomileri üzerinde tutmasıyla da açıklanabilir. Arık ve Turan (2006), yaptığı çalışmada nükleer santrallerin yeni istihdam alanları oluşturduğu ve ülke ekonomisine katkı sağladığını belirtmişler.

\section{Öneriler}

1. Fen Bilimleri öğretmenlerinin derslerinde sosyobilimsel konulara daha fazla yer vermesi ve zaman ayırmasının öğrencilerin bu konuları daha kalıcı ve etkili öğrenmelerine yardımcı olacağı ve karar verme becerilerinin gelişmesine katkı sağlayacağı düşünülmektedir.

2. Fen Bilimleri öğretmenlerine sosyobilimsel konular hakkında profesyonel gelişimlerini destekleyici eğitimler verilmesi önerilmektedir.

3. Sosyobilimsel konulara Fen Bilimleri derslerinde daha fazla yer verilmesi bu konuların yaşamın bir parçası olduğu farkındalığı kazandırabilir.

4. Fen Bilimleri öğretmenlerinin sosyobilimsel konular hakkında daha fazla araştırma yapmaları ve bu konular hakkında yayın yapan bilimsel dergi, kitaplar, medya aracılığıyla takip etmeleri teşvik edilebilir.

\section{Makalenin Bilimdeki Konumu}

Matematik ve Fen Bilimleri Eğitimi Bölümü/Fen Bilgisi Eğitimi

\section{Makalenin Bilimdeki Özgünlüğü}

Sosyobilimsel konular güncel ve sürekli gelişim içinde olduğundan dolayı Fen Bilimleri öğretmenleri gelişmelerden haberdar olmalı ve bunları öğrencilere aktarabilmelidir. Öğretmen, öğrencilerini her türlü gelişmeden haberdar etmeli, öğrencilerin ilgi ve meraklarını arttırmalı ve onları teşvik etmeli, ufuklarını geliştirmeli, sahip olduğu okuryazarlık bilgisini öğrencilerine aktarabilmeli, fen ile ilgili düşüncelerini ifade edebilmeli, fen-teknoloji ve toplumun birbirlerini nasıl etkilediğini anlamalarını sağlamalıdır (Yetişir, 2007). Öğrencilere bu özellikleri kazandırabilecek olan Fen Bilimleri öğretmenleri sosyobilimsel konular hakkında ne kadar bilgiye sahipse öğrencilerinin de daha bilgili olmalarını ve bu konuları öğrenmelerini sağlar. 


\section{Kaynaklar}

Albe, V. (2008). Students' positions and considerations of scientific evidence about a controversial socio-scientific issue. Science Education, 17(8-9), 805-827.

Arık, F. ve Turan, S. (2006). Nükleer enerji raporu: Nükleer santralin Konya'ya kurulabilirliği, getirileri ve götürüleri, Yeni İpek Yolu Konta Ticaret Odası Dergisi, 19(217), 25-32.

Bakırcı, H. Artun, H. Şahin, S. ve Sağdıç, M. (2018). Ortak bilgi yapılandırma modeline dayalı fen öğretimi aracılığıyla yedinci sınıf öğrencilerinin sosyobilimsel konular hakkındaki görüşlerinin incelenmesi. Eğitimde Nitel Araştırmalar Dergisi, 6(2), 207-237.

Cansız, N. (2014). Developing pre-service science teachers' socio-scientific reasoning through socio-scientific issues-focused course. Yayımlanmamış doktora tezi. Orta Doğu Teknik Üniversitesi Eğitim Bilimleri Enstitüsü, Ankara.

Cansı, N. ve Cansız, M. (2015). Views and knowledge of pre-service science teachers about nuclear power plants. International Journal on New Trends in Education and Their Implications, 6(2), 216-224.

Çapkınoğlu, E. (2015). 7. sınıf öğrencilerinin yerel sosyobilimsel konularda oluşturdukları argümantasyonların kalitesi ve karar verirken dikkate aldıkları faktörlerin incelenmesi. Yayımlanmamış doktora tezi, Eğitim Bilimleri Enstitüsü, Hacettepe Üniversitesi, Ankara.

Cebesoy, Ü. M. ve Dönmez-Şahin, M. (2013). Fen bilgisi öğretmen adaylarının sosyobilimsel konulara yönelik tutumlarının çeşitli değişkenler açısından incelenmesi. M.Ü. Atatürk Ĕ̈itim Fakültesi Eğitim Bilimleri Dergisi, 37, 100-117.

Clarkeburn, H., Downie, J. R., \& Matthew, B. (2002). Impact of an ethics programme in a life sciences curriculum. Teaching in Higher Education, 7(1), 65-79.

Cohen, L., \& Manion, L. (1994). Research methods in education. New York: Rutledge.

Dawson, V. M. (2011). A case study of the impact of introducing socio-scientific issues into a reproduction unit in a Catholic Girls’ school. T. D. Sadler (Ed.). Socio-scientific Issues in the Classroom (313-345). New York: Springer Dordect.

Demiral, Ü. ve Türkmenoğlu H. (2018). Fen bilgisi öğretmen adaylarının genetiği değiştirilmiş organizmalı besinler ile ilgili risk algılarının karar verme mekanizmalarıyla ilişkisinin incelenmesi. Yüzüncü Yıl Üniversitesi Eğitim Fakültesi Dergisi, 15(1), 1025-1053.

Demircioğlu, H. ve Vural, S. (2016). Ortak bilgi yapılandırma modelinin sekizinci sınıf düzeyindeki üstün yetenekli öğrencilerin kimya dersine yönelik tutumları üzerine etkisi. Hasan Âli Yücel Ĕ̌itim Fakültesi Dergisi, 13(1), 49-60. 
Domaç, G. G. (2011). Biyoloji ĕgitiminde toplum bilimsel konuların öğretilmesinde argümantasyon tabanlı ögrenme sürecinin etkisi. Yayımlanmamış yüksek lisans tezi. Eğitim Bilimler Enstitüsü, Gazi Üniversitesi, Ankara.

Ebenezer, J., Chacko, S., Kaya, O. N., Koya, S. K., \& Ebenezer, D. L. (2010). The effects of common knowledge construction model sequence of lessons on science achievement and relational conceptual change. Journal of Research in Science Teaching, 47(1), 25-46.

Goloğlu, S. (2009). Fen eğitiminde sosyobilimsel aktivitelerle karar verme becerilerinin geliştirilmesi: dengeli beslenme. Yayımlanmamış yüksek lisans tezi, Eğitim Bilimler Enstitüsü. Marmara Üniversitesi, İstanbul.

Han-Tosunoğlu, Ç. (2018). Biyoloji öğretmenlerinin sosyobilimsel konularla ilgili pedagojik alan bilgilerinin incelenmesi. Yayımlanmamış doktora tezi, Eğitim Bilimler Enstitüsü, Marmara Üniversitesi, İstanbul.

Hogan, K. (2002). Small groups' ecological reasoning while making an environmental management decision. Journal of Research in Science Teaching, 39(4), 341-368.

Karaaslan, E. H. ve Ayas, A. (2016). Fen eğitiminde bilimsel açıklama ve önemi. Ahi Evran Üniversitesi Kırşehir Ĕ̈itim Fakültesi Dergisi, 17(3), 101-120.

Karışan, D. (2014). Exploration of pre-service teachers' reflective judgment and argumentation skills revealed in a socio-scientific issues-based inquiry laboratory course. Yayımlanmamış doktora tezi, Eğitim Bilimleri Enstitüsü, Orta Doğu Teknik Üniversitesi, Ankara.

Kılınç, A., Demiral, U. ve Kartal, T. (2017). Resistance to dialogic discourse in SSI teaching: The effects of an argumentation-based workshop, teaching practicum, and induction on a pre-service science teacher. Journal of Research in Science Teaching, 54(6), 764-789.

Kutluca, A. Y. (2012). Fen ve teknoloji ögretmen adaylarının klonlamaya ilişkin bilimsel ve sosyobilimsel argümantasyon kalitelerinin alan bilgisi yönünden incelenmesi. Yayımlanmamış yüksek lisans tezi, Eğitim Bilimleri Enstitüsü, Abant İzzet Baysal Üniversitesi, Bolu.

Lee, M. K., \& Erdogan, I. (2007). The effect of science-technology-society teaching on students' attitudes toward science and certain aspects of creativity. International Journal of Science Education, 29(11), 1315-1327.

Miles, M. B., \& Huberman, A. M. (1994). Qualitative data analysis: an expanded sourcebook. California: Sage Publications. 
Nielsen, J. A. (2012). Science in discussions: An analysis of the use of science content in socioscientific discussions. Science Education, 96(3), 428-456.

Nuhoğlu, H. (2014). Güncel sosyobilimsel konulara yönelik sistem dinamiği temelli kurulan öğrenci modellerinin değerlendirilmesi. Kuram ve Uygulamada Eğitim Bilimleri Dergisi, 14(5), 1957-1975.

Öztürk, M., Akdeniz, A. R. ve Bakırcı, H. (2017). Bilgisayar destekli öğretim uygulamalarının ortaokul öğrencilerinin bilimsel düşünme becerileri üzerine etkisi. Yüzüncü Yll Üniversitesi Ĕ̈itim Fakültesi Dergisi, 14(1), 611-639.

Roth, W. M., \& Lee, S. (2004). Science education as/for participation in the community. Science Education, 88(2), 264-291.

Sadler, T. D. (2004). Informal reasoning regarding socio-scientific issues: A critical review of literature. Journal of Research in Science Teaching, 4, 513-536.

Sadler, T. D., \& Zeidler, D. L. (2005). Patterns of informal reasoning in the context of socioscientific decision making. Journal of Research in Science Teaching, 42, 112-138.

Sadler, T. D., \& Zeidler, D. L. (2009). Scientific literacy, PISA, and socio-scientific discourse: assessment for progressive aims of science education. Journal of Research in Science Teaching, 46(8), 909-921.

Sağlam, Y., Karaaslan, E. H. ve Ayas, A. (2014). Creating a taken-as-shared understanding for scientific explanation: classroom norm perspective. International Journal of Education in Mathematics, Science and Technology, 2(2). 149-1463.

Sibıç, O. (2017). Fen bilgisi öğretmen adaylarının sosyobilimsel konulara ve sosyobilimsel konu temelli ögretime yönelik görüşleri. Yayımlanmamış Yüksek Lisans Tezi. Eğitim Bilimler Enstitüsü, Yıldız Teknik Üniversitesi, İstanbul.

Soysal, Y. (2012). Sosyobilimsel argümantasyon kalitesine alan bilgisi düzeyinin etkisi: Genetiği değiştirilmiş organizmalar. Yayımlanmamış yüksek lisans tezi. Eğitim Bilimler Enstitüsü, Abant İzzet Baysal Üniversitesi. Bolu

Taşpınar, P. (2011). Sosyobilimsel tartışma destekli sağlık ĕgitimi etkinliklerinin ilköğretim 5. sınıf öğrencilerinde săglı bilincinin ve içerik bilgisinin gelişimine etkisi. Yayımlanmamış yüksek lisans tezi. Eğitim Bilimler Enstitüsü, Marmara Üniversitesi, İstanbul.

Topçu, M. S. (2008). Fen öğretmen adaylarının sosyobilimsel konular hakkındaki kritik düşünme yetenekleri ve bu yetenekleri etkileyen faktörler. Yayımlanmamış doktora tezi. Eğitim Bilimler Enstitüsü, Orta Doğu Teknik Üniversitesi, Ankara. 
Topçu, M. S. (2010). Development of attitudes towards socio-scientific issues scale for undergraduate students. Evaluation and Research in Education, 23(1), 51-67.

Topçu, M. S. (2017). Sosyobilimsel konular ve ögretimi (2. Baskı). Ankara: Pegem Akademi Yayınc1lik.

Topçu, M. S., Muğaloğlu, E. Z. ve Güven, D. (2014). Fen eğitiminde sosyobilimsel konular: Türkiye örneği. Kuram ve Uygulamada Ĕ̆itim Bilimleri, 14 (6),1-22.

Wu, Y. T., \& Tsai, C. C. (2011). The effects of different on-line searching activities on high school students' cognitive structures and informal reasoning regarding a socio-scientific 1ssue. Research Science Education, 41(5), 771-785.

Yahaya, J. M., Zain, A. M. N. \& Karpudewan, M. (2012). Understanding socio-scientific issues in a low literate society for the achievement of the millennium development goals. World Academy of Science, Engineering and Technology, 72, 123-126.

Yetişir, M. Ġ. (2007). Illköğretim fen bilgisi öğretmenliği ve sınıf öğretmenliği birinci sınıfında okuyan ögretmen adaylarının fen ve teknoloji okuryazarlık düzeyleri. Yayımlanmamış yüksek lisans tezi. Eğitim Bilimler Enstitüsü, Gazi Üniversitesi, Ankara.

Yıldırım, A. ve Şimşek, H. (2011). Sosyal bilimlerde nitel araştırma yöntemleri. Ankara: Seçkin Yayıncılık.

Yolagiden, C. (2017). Öğretmen adaylarının fen ögrenme becerisi, fen okuryazarlı̆̆l ve sosyobilimsel konulara yönelik tutumları arasındaki ilişsininin araştırılması. Yayımlanmamış yüksek lisans tezi, Fen Bilimleri Enstitüsü, Sütçü İmam Üniversitesi, Kahramanmaraş.

Zeidler, D. L. Sadler, T. D. Applebaum, S. \& Callahan, B. E. (2009). Advancing reflective judgment through socio-scientific issues. Journal of Research in Science Teaching, 46 (1), 74-101. 


\section{Araștırma Makalesi}

ISSN: 1305-2020

\section{Summary}

\section{Introduction}

One of the basic philosophies of the Science Course Curriculum is to ensure that students are gain science literacy. Teachers' perspectives, knowledge levels and attitudes play an important role in students' literacy. Many studies have shown that teachers' proficiency in socio-scientific issues is effective on students' science literacy. (Clarkeburn, Downie \& Matthew, 2002; Wu \&Tsai, 2011). It can be argued that raising individuals who can discuss socio-scientific issues will have positive implications on the education of science readers (Sadler \& Zeidler, 2005; Topçu, 2010). Therefore, in this study, science teachers' attitudes, opinions and knowledge levels on socio-scientific issues are examined.

Research on socio-scientific issues generally focus on teacher candidates, and there are very few studies on how science teachers approach socio-scientific issues. Therefore, it has become important to investigate the science teachers' attitudes towards socio-scientific topics, their knowledge and views on these topics. This research aims to reveal the attitudes and opinions of science teachers on socio-scientific issues and seek responses to answer the following questions.

1. What are the science teachers' attitudes towards socio-scientific issues?

2. What are the views of science teachers about the teaching of socio-scientific issues?

\section{Method}

The research employs special case method. The special case method allows the researcher to focus on the characteristics of a case by using different data collection tools (Cohen \& Manion, 1994). The data is expected to test and support each other using more than one data collection method (Yıldırım \& Şimşek, 2011). The sample of the research consists of 289 Science teachers working in the central districts of Van in the 2018-2019 academic year. The data collection tools are the socio-scientific Attitude Scale and semi-structured interviews. Descriptive statistics were used to analyse the quantitative data whereas content and descriptive analyses for used qualitative data.

\section{Findings}

When Table 1 is analysed, it can be seen that science teachers' arithmetic mean of the subscale of benefit and importance of the socio-scientific issues is 56.65. The average score of the subscales of enjoying socio-scientific issues is 26.55 and the anxiety about socio-scientific topics is 33.14. The average total scale score is 38.78 . 
Table 3 shows that science teachers define their views on socio-scientific issues as social, controversial, open-ended, science-related, and complex. In addition, some science teachers have specified such issues with science and technology, environment, nuclear energy and sustainable development.

When Table 4 is analysed, teachers' views on the teaching of socio-scientific topics are gathered under two themes. Teachers have stressed that methods / techniques such as discussion, brainstorming, case study, question answer and argumentation should be used in the teaching of socio-scientific topics. Some science teachers expressed tools such as smart board, projection, simulation, and animation can also be used as assisting technologies in teaching.

\section{Discussion and Conclusion}

It was determined that the average scores of the science teachers regarding the three sub-scales of the attitude scale were different (See Table 1). The average scores of the items on the benefits and importance of the socio-scientific issues of the teachers were high, while the average scores of the items on the attitudes, likes and anxiety items were low.

Teachers mostly expressed positive opinions about the importance of socio-scientific issues and this can be explained by the fact that these issues are included in the curriculum and they are always on the agenda or in the visual and press media. They also added that socioscientific topics are also important in helping people lead healthy lives. Topçu, Muğaloğlu \& Güven (2014) found in their research that when the socio-scientific issues were included in the curriculum, the teachers researched these and were eager to receive in-service training. It was observed that these issues were discussed more and more by the experts in the written and visual media (Sadler, 2004; Yahaya, Zain \& Karpudewan, 2012). From this point of view, it can be said that the science teachers are knowledgeable about socio-scientific subjects, which echoes the results of the studies in the literature.

Science teachers stated several ideas about socio-scientific issues. (See Table 3). For instance, they defined such topics as controversial, open-ended and science-related subjects. In addition, they related them to the society, expressed that there was no consensus on what socioscientific topic is, and associated it with environmental problems. It was also noted that teachers conduct research on and follow studies related to socio-scientific issues and this may be triggered by the inclusion of such studies in the textbooks. In addition to this, the problems that concern science and society in daily life are the problems that are always considered in daily life and that they make up the popular science, which may have also nourished teachers' interests. When the studies on this subject were examined, we can argue that socio-scientific 
issues were defined as problems involving both scientific and social dilemmas (Sadler \& Zeidler, 2005). Similarly, Topçu (2010) defined socio-scientific issues as complicated, uncertain topics. This study shows that teachers' conceptualization of socio-scientific topics also echo the findings of the literature.

Science teachers stated that brainstorming, case study, debate and question-answer technique should be used in the teaching of socio-scientific topics (See Table 4). It can be explained by the fact that these teaching techniques are student-centered, enable discussion, and help teachers discuss the everyday issues in the classroom. For example, brainstorming technique can help each student to speak their own opinion and teach students to be respectful of different thoughts and original ideas. In addition, some teachers suggested the smart board, simulation, projection and animation, or visual methods and techniques should also be utilized in teaching. Teachers' these suggestions can be explained by the fact that it is a technology era, students are interested in technology supported lessons, and technological tools address multiple sensory organs. The infrastructures of the technological instruments in their schools also enable the students to learn better, enable teachers to use their time more efficiently, and create permanent learning (Öztürk, Akdeniz \& Bakırc1, 2017). 